\title{
Reviews and syntheses: the first records of deep-sea fauna - a correction and discussion
}

\author{
W. Etter and H. Hess \\ Naturhistorisches Museum, Augustinergasse 2, 4001 Basel, Switzerland \\ Correspondence to: W. Etter (walter.etter@bs.ch)
}

Received: 9 April 2015 - Published in Biogeosciences Discuss.: 15 June 2015

Accepted: 28 October 2015 - Published: 12 November 2015

\begin{abstract}
The soundings in deep waters of Baffin Bay, together with the recovery of a basket star by John Ross in 1818, was a milestone in the history of deep-sea research. Although the alleged water depths of up to $1950 \mathrm{~m}$ were by far not reached, these were nevertheless the first soundings in deep bathyal (to perhaps uppermost abyssal) depths. Furthermore, the recovery of a benthic animal proved that animal life existed at great depths. Yet this was not the first published record of deep-sea fauna as it is often portrayed. This merit goes to accidental catches of the stalked crinoid Cenocrinus asterius that were recovered with fishing lines from upper bathyal environments near Antillean islands. In addition, the description of several deep-sea fishes considerably predated the John Ross episode.
\end{abstract}

\section{Introduction}

When books or review-papers give in their introductory section a short overview of the history of deep-sea research, the recovery of a basket star by Sir John Ross in 1818 from deep waters of the Northwest Passage is often cited as the first organism that was brought up from the deep sea (Menzies et al., 1973; Tyler, 1980; Gage and Tyler, 1991; RamirezLlodra et al., 2010). This is not correct. The first published record is considerably older: the upper bathyal stalked crinoid Cenocrinus asterius (Linné) was brought up, probably on fishing lines on several occasions, in the Caribbean (Thomson, 1873), and two specimens reached Europe and were already described in 1761 and 1762, respectively. In addition, several descriptions of deep-sea fishes appeared in the late 18th and early 19th century, again predating Ross' finding of the basket star.
To put these historical finds in context, we want to give in the following paragraphs an overview of

- deep soundings and dredgings up to the times of the Challenger expedition;

- the historical records of basket stars and stalked crinoids;

- possible explanations why the Ross expedition became uncritically cemented in the deep-sea literature, whereas the earlier finds of Cenocrinus asterius and other captures of deep-sea creatures were neglected.

For practical reasons all the depths given in the historical literature are converted to meters.

\section{Sounding and sampling the deep sea}

Sounding water depths with line and plummet had been in use since the first ships went to the oceans, yet it had always been the shallow waters near the land that were in the focus of the navigators. Those soundings were used for the first time in nautical maps in the 16th century, and isobathic coastal maps were introduced in 1737 (Murray, 1895; Murray and Hjort, 1912).

We here follow Gage and Tyler (1991); Herring (2002); Tyler (2003); Thistle (2003); Snelgrove and Grassle (2008) and others and let the deep sea start below $200 \mathrm{~m}$. As bathyal species we designate those that have their main distribution between 200 and $1000 \mathrm{~m}$. The first scientific attempt at sounding the deep sea is ascribed to Magellan who tried in 1521 unsuccessfully to reach the bottom between two pacific coral islands with a line measuring between 180 and 
$360 \mathrm{~m}$ (Murray, 1895; Murray and Hjort, 1912). The conclusion that the expedition had here arrived at the deepest part of the ocean appears rather naïve (Murray, 1895).

The next sounding that found its way into the deep-sea literature was in an apparent depth of $1250 \mathrm{~m}$, recorded in 1773 east of Iceland by Captain Constantine Phipps aboard the HMS Racehorse (Rice, 1975), but this depth must be read with caution (see below). The soundings undertaken in 1818 during the John Ross expedition searching for the Northwest passage in the Arctic (Ross, 1819) with alleged depths of up to $1950 \mathrm{~m}$ in Baffin Bay appeared like a quantum leap. Furthermore, for the first time an animal was brought up from a depth that seemed to be accurately recorded. But of course there are major problems with this expedition. The captain's diary, the shipboard recordings, and the subsequent publications were inaccurate and sometimes contradictory (Rice, 1975). The actual depths of the deepest soundings were only around half of the published values and did certainly not exceed $1100 \mathrm{~m}$ (Rice, 1975). The famous basket star that was allegedly caught entangled in the sounding line $370 \mathrm{~m}$ above the weight (!) must also have come from a depth of around $1000 \mathrm{~m}$. This is still impressive, and had this result been more widely disseminated, it had perhaps prevented the uncritical prevalence of Forbes' theory of an azoic zone below 550$600 \mathrm{~m}$ (Forbes, 1844; Rice, 1975; Anderson and Rice, 2006).

Similar problems with a large divergence between apparent and true depth certainly apply to all the deep soundings of the early 19th century. The James Clark Ross expedition for example allegedly sounded in the Atlantic east of Brazil with a line in excess of $8400 \mathrm{~m}$ without reaching the bottom (Ross, 1847; Murray, 1895). Yet such depths are nowhere to be found in this region.

The scientific sampling of the deep sea received a veritable boost when dredging the seabed became possible at ever greater depths. The brilliant naturalist Edward Forbes was a pioneer in that field. By 1839 he had already dredged at various places around the north of Great Britain and Ireland (Anderson and Rice, 2006) and had developed a zonation of life from the littoral down to mid-shelf depths. In 1840 Forbes joined a campaign on the HMS Beacon to conduct surveys in the eastern Mediterranean. It was his work on the bathymetric distribution of life in the Aegean Sea, based on more than 100 dredgings to a depth of $240 \mathrm{~m}$ (Murray, 1895), that proved most influential. Forbes noted that life became ever sparser with increasing depth and concluded by interpolation that life would probably vanish below a depth of about $550 \mathrm{~m}$ (Forbes, 1844).

Such a theory of the azoic deep sea had already been developed, e.g., by the French naturalist François Péron, who thought that the bottom of the deep sea was covered with eternal ice (!) and therefore without life (Murray, 1895). Likewise, the British geologist Henry de la Beche had postulated a lifeless deep sea on theoretical grounds (Anderson and Rice, 2006), but it was the detailed investigations of Forbes that ensured a staying power for the theory of azoic deep-sea bottoms. In those days it seemed only logical that the dark, ice-cold environment without primary production where huge pressures acted would be hostile to life (Anderson and Rice, 2006).

Of course there were already strong indications in 1840 that life was present in the deep sea below $550 \mathrm{~m}$. The John Ross Arctic expedition had in 1818 recovered life from much greater depths. Dredgings made between 1839 and 1843 during the Antarctic expedition of James Clark Ross had brought up samples full of life from depths up to $730 \mathrm{~m}$ (Murray, 1895; but again these depths must be read with caution).

Especially influential was the work of the Norwegian naturalist Michael Sars who published in 1850 a list of animals that were dredged from depths of more than $550 \mathrm{~m}$ off the coast of northern Norway (Murray, 1895). Later work was done together with his son Georg Ossian Sars, and they published their new finds from deep waters, including the stalked crinoid Rhizocrinus lofotensis (Sars, 1868). This new species was the first stalked crinoid to be brought up from a defined depth. It spurred considerable interest among fellow marine researchers, mainly Thomson and Carpenter, and had a large impact on the future direction of deep-sea research (see below).

When a telegraph cable between Britain and America was being planned, further evidence for life at great depths was found. In 1860, Georg Charles Wallich aboard the HMS Bulldog sounded and sampled the seabed in the northern Atlantic. In one sounding to a depth of $2300 \mathrm{~m}$, he found several brittle stars entangled around the rope (Wallich, 1862). For Wallich this proved that life existed at great depths and was by far the most important sounding ever (and at the same time he dismissed similar results obtained by others; see Rice et al., 1976; Rozwadowski, 2005). Yet his results and conclusions were not widely accepted, which later led him to engage in a bitter feud with Thomson and Carpenter (Rice et al., 1976).

Conclusive proof for the existence of life on very deep bottoms came when a telegraph cable laid in 1857 between Sardinia and the north African coast failed in 1860. The $70 \mathrm{~km}$ brought up for repair came from a depth of more than $2000 \mathrm{~m}$, and, together with the cable, many animals from the seabed were recovered. Most notable were some specimens that were attached to the cable itself, especially a coral of the genus Caryophyllia that had its base moulded on the structure of the cable (Murray, 1895).

Further indications for rich life at great depths came from various sources, e.g., the dredgings from Torrell's expedition to Spitsbergen in 1864, and the recovery of the glass sponge Hyalonema by fishermen, first in Japan, then in 1868 from the deep sea off Portugal (Murray, 1895). In the following years sporadic successful dredgings from deep environments were obtained, e.g., 1867 and 1868 by Pourtalès and Mitchell in the Strait of Florida down to 1555 m (Agassiz, 1888). But systematic investigations of the deep-sea floor really only commenced with the British expeditions aboard the HMS Lightning in 1868 and the HMS Porcupine in 1869/1870. 
The objective of these expeditions was to investigate the distribution of life on the deep-sea floors, to look for "living fossils" and to document the temperatures of Atlantic waters (Mills, 1983; Rozwadowski, 2005). Especially the Porcupine cruise was highly successful, with many dredgings full of life to a depth of more than $3500 \mathrm{~m}$ (Murray, 1895; Mills, 1983; Rozwadowski, 2005). It was also during these expeditions that new dredges, sounding devices and other equipment were tested for their application in deep-sea research (Mills, 1983; Rozwadowski, 2005). The results of these expeditions were also instrumental for the writing of what could be called the first textbook on deep-sea biology (Thomson, 1873). Finally, during the subsequent circumnavigation of the HMS Challenger (1872-1876) it was proven once and for all that life existed in all oceans and at all depths (although life at the greatest hadal depths, $>10000 \mathrm{~m}$, was only finally documented by the Danish deep-sea expedition aboard HDMS Galathea in 1951; Bruun, 1956).

\section{The neglected part of deep-sea sampling}

Yet sampling of deep-sea animals was not restricted to scientific campaigns that sounded and dredged the bottoms. This environment was also sampled by fishermen who put their lines and hooks down to considerable depths and retrieved many unanticipated species in addition to their planned catches. It was such findings that provided the earliest records of deep-sea life. These were stalked crinoids from the Caribbean (see below) and various deep-sea fishes from the Azores, Madeira, northern Spain, Sicily, and Antillean islands (e.g. Günther, 1887).

These fishes include the oarfish Regalecus glesne (Ascanius, 1772), the hatchetfish Sternoptyx diaphana (Hermann, 1781), the ribbonfish Trachipterus trachypterus (Gmelin, 1789), the tube-eye Stylephorus chordatus (Shaw, 1791), the viperfish Chauliodus sloani (Bloch and Schneider, 1801), the scaly dragonfish Stomias boa (Risso, 1810), and the grenadier Coelorinchus caelorhincus (Risso, 1810). Most of these had been caught floating near the surface and sometimes in coastal environments (Günther, 1887) but they nevertheless are true deep-sea species.

Because the echinoderm groups of the basket stars and the stalked crinoids played a crucial role in the history of deepsea research, both these groups are treated in more detail below.

\section{The historical record of basket stars}

Most basket stars live on hard bottoms, often clinging to corals or sponges, in deeper shelf and upper bathyal environments (Lyman, 1882; Koehler, 1909; Clark, 1915; Hendler, 1996) but some also occur in water depths as shallow as $10 \mathrm{~m}$ as well as in abyssal depths (e.g. Clark, 1915; Emson et al., 1991; Hendler, 1996). Up to the times of the first deep-sea ex- peditions every finding/recovery of these animals was a lucky incident that, not least because of their strange appearance, received considerable attention. Their unusual morphology is reflected in their naming: "Caput medusae", "Gorgonocephalus", head of the medusa. They are among the largest ophiuroids and are voracious predators that feed on megaplankton (Emson et al., 1991; Rosenberg et al., 2005).

The oldest valid name is Gorgonocephalus caputmedusae (Linné, 1758) but different basket stars were already recorded earlier. Rondelet described and nicely illustrated the Mediterranean species (Rondelet, 1555, p. 121), which was later copied by Gessner (1558) and Aldrovandi (1602). In 1675, a northern European species was described for the first time (Martens, 1675; he gives a strange description $\mathrm{p}$. 88: "The other starfish, body decagonal, below (mouth) sixrayed star"; our translation), which might indicate that this specimen was hexamerous. This was followed in 1705 by an Indo-Pacific basket star (Rumph, 1705). Linck (1733) was probably the first to recognize several distinct species, but his names predate the 10th edition of Linné's Systema Naturae and are hence not valid.

Linné (1758) based his name on a specimen from Norway that he had described earlier (Linné, 1754). It is not evident why he did not mention the description of Rondelet (or Gessner), as he usually did so, but the various forms recognized by Linck (1733) were for Linné all the same. Today, of course, these are indeed recognized as different species: Rondelet's Mediterranean species is Astrospartus mediterraneus (Risso, 1826) and the one described by Martens from "Weyhegatt" (probably Weygate Straits, Svalbard) appears to be Gorgonocephalus arcticus (Leach, 1819), although six jaws are otherwise not known in that species (S. Stöhr, personal communication, 2014).

Rumph's species cannot be determined, as the figures do not show any key characters. However, Gorgonocephalus caputmedusae can be excluded (S. Stöhr, personal communication, 2014). Unfortunately, that name is routinely used when Rumph's specimen is discussed in the literature (e.g. Reich (2010) in his essay on the "Swabian Caput Medusae", which is the crinoid Seirocrinus subangularis (Miller, 1821) from the lower Jurassic Posidonia Shale). When describing natural wonders of the island Cuba, Parra (1787) mentioned and figured two "Estrella ramosa" that were the first published basket stars from the Caribbean. The figures are not very accurate but the specimens probably belong to Astrophyton muricatum (Lamarck, 1816), which has a rather wide distribution in the Caribbean (Hendler et al., 1986).

The specimen that Ross recovered in Baffin Bay was Gorgonocephalus arcticus (Leach, 1819), and not Astrophyton linckii (Lyman, 1882) (= Gorgonocephalus caputmedusae), as has been frequently indicated (Menzies et al., 1973; Tyler, 1980; Ramirez-Llodra et al., 2010; see Leach, 1819). Ross' specimen is perhaps still in the possession of the Natural History Museum in London (Rice, 1975; Anderson and Rice, 2006). This species (Fig. 1) also occurs in the eastern Arc- 


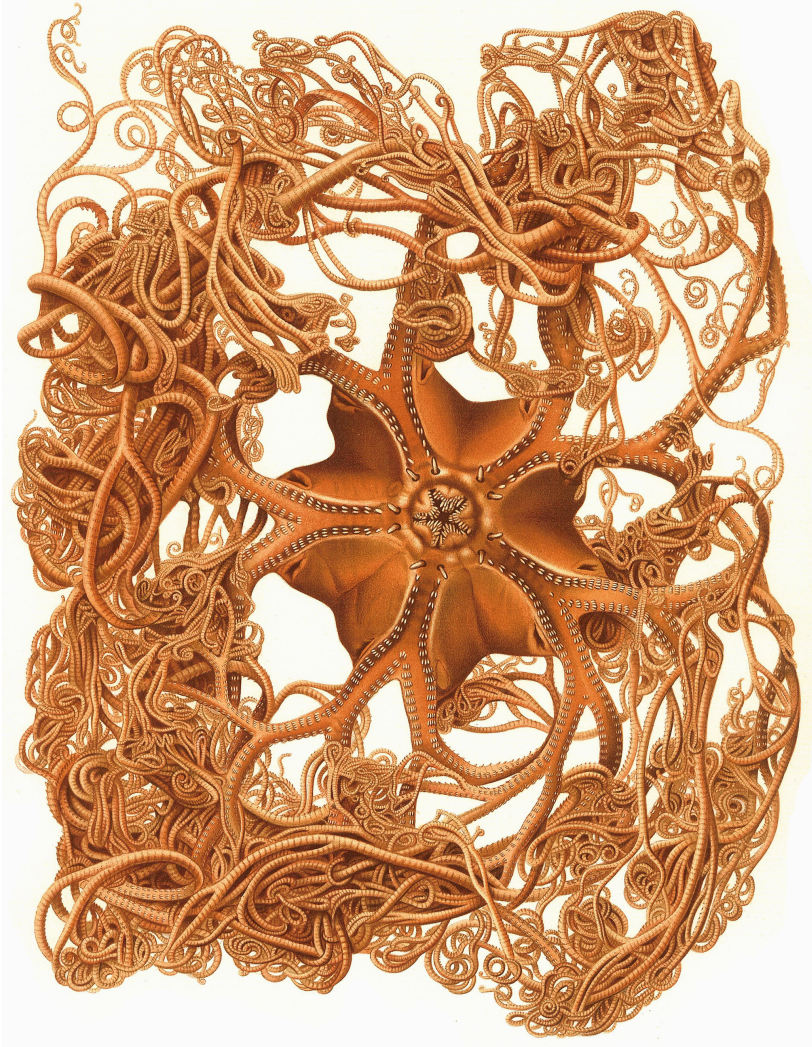

Figure 1. Gorgonocephalus arcticus (Leach, 1819) (from Koehler 1909, pl. 9; as Gorgonocephalus agassizi; Stimpson, 1854). This is the species that was caught during the John Ross expedition.

tic Atlantic, e.g., around Svalbard and off Norway (Koehler, 1909), and in the Kola fjord in the region of Murmansk (Fedotov, 1926). Like Gorgonocephalus caputmedusae, G. arcticus (Astrophyton agassizi (Stimpson, 1854) is a junior synonym according to Stöhr, 2014) is encountered from the infralittoral to deeper bathyal environments (Grieg, 1900; Fedotov, 1926) but mostly between 15 and $100 \mathrm{~m}$ (Fedotov, 1926). It is therefore, strictly speaking, not a deep-sea species.

\section{The historical record of stalked crinoids and the notion of "living fossils"}

The finds of stalked crinoids from deep waters of the Caribbean around 1750 must be considered the first records of deep-sea animals that were published. Yet they were not recognized as that because there were no sounding records tied to those catches, but today we know that they are bathyal species and therefore true deep-sea forms. Already then, however, it was obvious that these finds somehow related to fossils from the distant past, and the concept of "living fossils" was developed almost 100 years before Darwin (1859) introduced this term when discussing the platypus and the South American lungfish (Rudwick, 2005).

Much later another species was recovered from a known depth in bathyal environment off northern Norway and immediately caught the attention of the scientific community. It was recognized both as a deep-sea animal occurring well below the depth limit for life according to Forbes and his disciples, as well as a living fossil (see section on Conocrinus lofotensis). This proved to have a major impetus for the succeeding planning of deep-sea explorations.

\subsection{The "sea palm" Cenocrinus asterius}

Guettard (1761) described the first known stalked crinoid in detail as "Palmier marin" (Fig. 2). Linné (1767) later named it Isis asteria and Lamarck (1816) Encrinus caput medusa. It is an isocrinid and is now known as Cenocrinus asterius (Linné, 1767). The remains of the animal were kept as "palmier marin" in the cabinet (collection) of a M. de Boisjourdain at Martinique who obtained it from an officer of a vessel making port there. Unfortunately, the exact location of the catch, presumably by a fisherman, is unknown. However, this crinoid is common in the Caribbean at $200-300 \mathrm{~m}$ although it has also been observed as shallow as $183 \mathrm{~m}$ (Macurda Jr. and Meyer, 1974). It was in fact Madame Boisjourdain who made the link between the living animal and the fossil remains of isocrinids with their pentagonal column and star-shaped columnal facets (Guettard, 1761). Guettard thus presented this animal as a survivor of a disappeared marine world whose pierres étoilées (encrinites, entroques, trochites) were topics of doubts as to their nature. Guettard seemed to have been happy to be able to resolve these doubts. He even went on to count the total number of ossicles of the crinoid and arrived at the astonishing figure of at least 128 675. This was even more than Rumph (1705) had counted for his "Caput medusae" with 81840 ossicles. Guettard also mentioned a superficially similar animal that was caught by whale-fishers in deep waters off Greenland and described by Mylius (1753). Yet this was certainly no crinoid (Guettard, 1761) but rather an umbellulid pennatulacean (see Ellis, 1755; see also Walch, 1769).

Shortly thereafter a second specimen was brought to the attention of the public. It was found near Barbados and described by Ellis (1762). With only the lower part of the crown preserved it was less complete than Guettard's specimen (Fig. 3). This crinoid has survived and is now in the Hunterian Museum \& Art Gallery in Glasgow (M. Reilly, personal communication, 2015). Ellis also compared his "Encrinus" to British fossils from the Lower Jurassic. In the meantime, Cenocrinus asterius has become one of the most studied living stalked crinoids, including numerous in situ observations (Baumiller et al., 1991). 


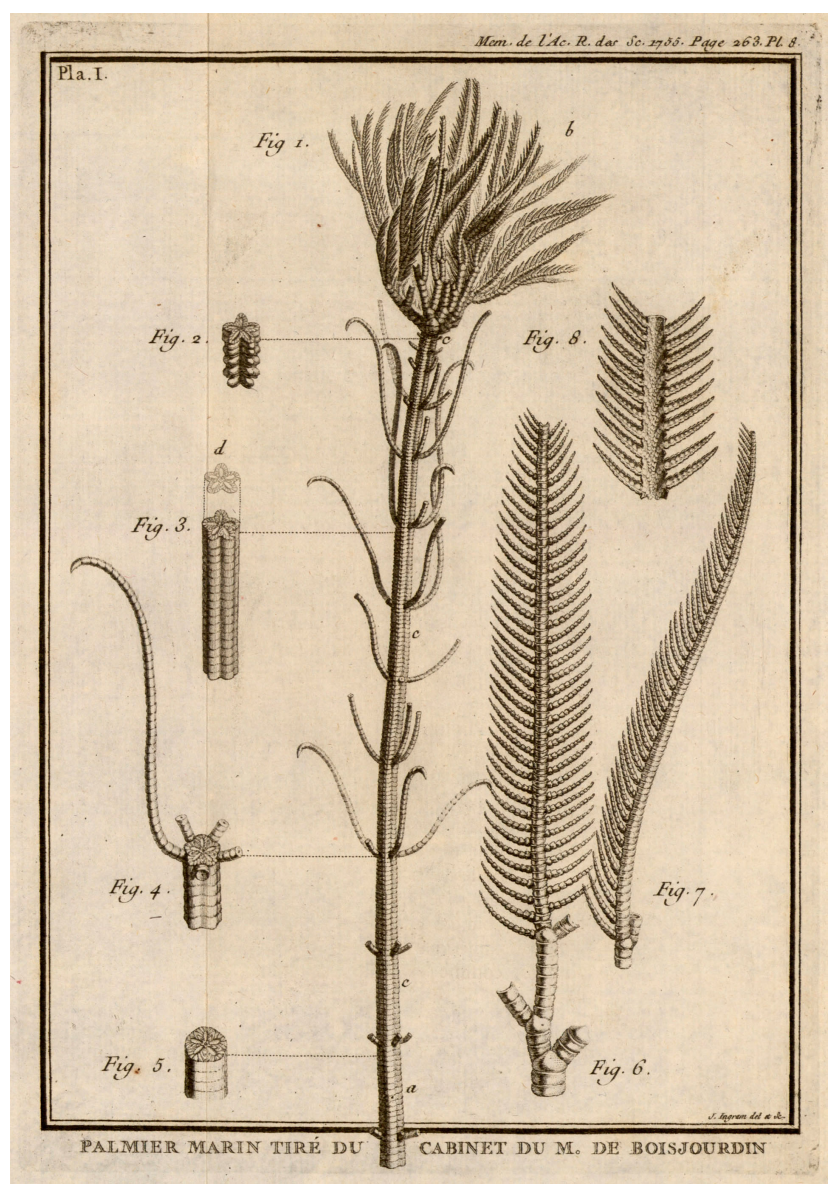

Figure 2. Cenocrinus asterius (Linné, 1767) (from Guettard, 1761, pl. 8; as "Palmier marin"). This was the first modern stalked crinoid that was described.

\subsection{Crinoid finds between 1762 and 1864}

In the years after the publications of Guettard (1761) and Ellis (1762), new stalked crinoid species were sporadically recovered. They were all accidental catches from the Caribbean with no defined depth attached to them. They were largely neglected by marine biologists and had no impact on deepsea research in the following decades.

In his description of natural objects of Cuba, Parra (1787) gave a figure and a description of another isocrinid and called it "palma animal". He also undertook the sport of counting the ossicles of this crinoid and arrived at 62660 without counting the stalk and the cirri. His figure was later reproduced by Gervais (1835) who erected the new species Encrinus parrae. This species is today recognized as Endoxocrinus (Endoxocrinus) parrae (Gervais in Guérin, 1835), which occurs over a depth range of $154-520 \mathrm{~m}$ in the tropical Western Atlantic, and may be locally abundant (David et al., 2006; Améziane and Baumiller, 2007).

Shortly thereafter another crinoid was described from deep waters of the Caribbean. It was the peculiar Holopus rangii

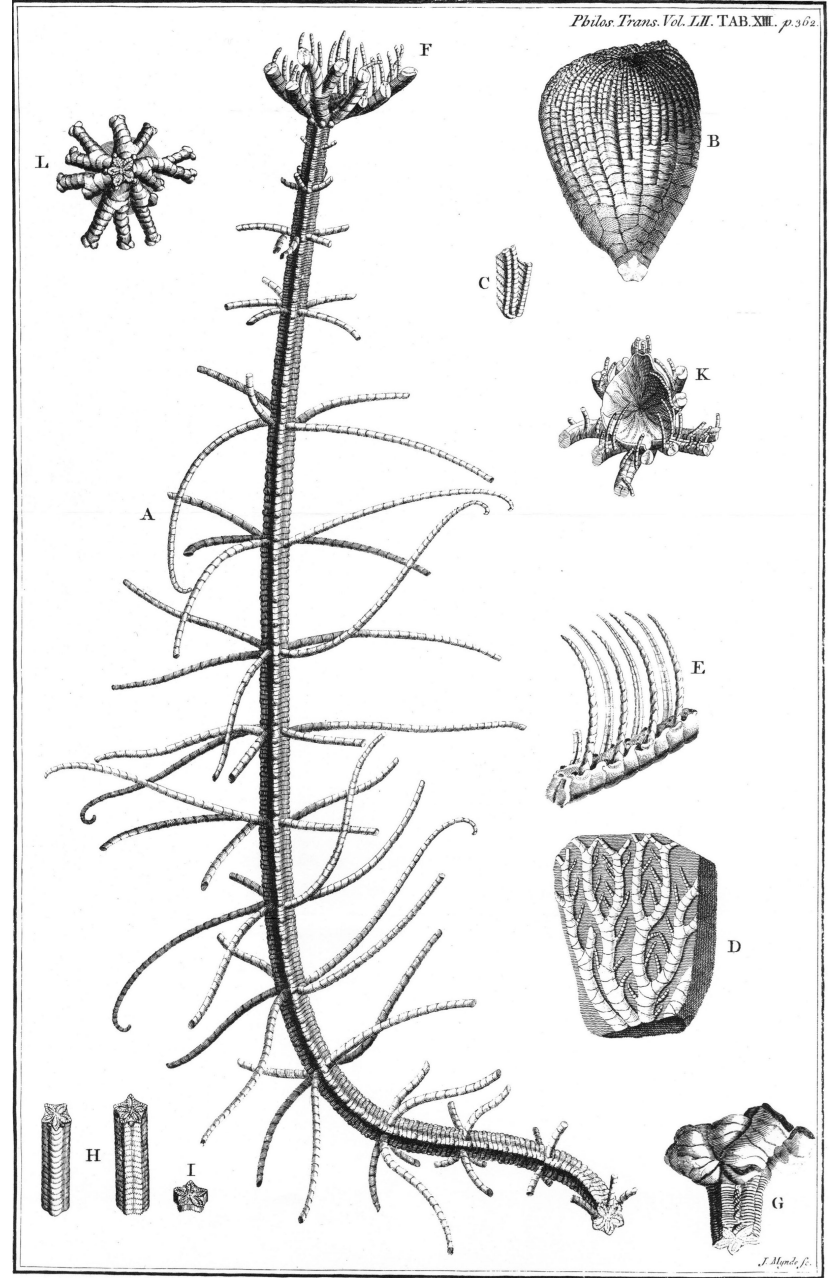

Figure 3. Cenocrinus asterius (Linné, 1767) (from Ellis, 1762, pl. 13; as "Encrinus" from Barbados). This specimen was the second modern stalked crinoid that was described. Also figured are fossil forms: B and C are from the Early Jurassic (Sinemurian) of Pyrton-passage. The site has furnished Isocrinus (Chladocrinus) tuberculatus (Miller, 1821) but the drawings are too stylized for proper assignment. D is an indeterminable crinoid copied from Rosinus (1719). G shows the upper part of the stalk and the base of the crown of Eocomatula interbrachiatus (Blake, 1876) from the Early Jurassic (Pliensbachian) of Marston Trussell.

d'Orbigny (1837) which cements to the substrate (d'Orbigny, 1837; Grimmer and Holland, 1990). This species has been observed on hard bottoms, preferentially under overhangs, in depths between 100 and $654 \mathrm{~m}$, but its main distribution is upper bathyal (Améziane et al., 1999; Donovan and Pawson, 2008). A further species, Pentacrinus muelleri, was erected by Oersted in 1856 and later described in more detail by Lütken (1864). However, P. muelleri is considered today a junior synonym of Endoxocrinus parrae (David et al., 2006). Finally, Pentacrinus decorus was described by Thomson in 1864 (see Carpenter, 1884). This species which is now known as Neocrinus decorus (Thomson, 1864) has a wide 
distribution from the Bahamas to Venezuela and occurs between 154 and $1220 \mathrm{~m}$ (Meyer et al., 1978; Pawson et al., 2009). It is semi-sessile and is capable of rapidly crawling along the bottom with the aid of its arms (Baumiller and Messing, 2007).

\subsection{Conocrinus lofotensis}

Sars (1864) mentioned the find of a new stalked crinoid named Rhizocrinus lofotensis (Fig. 4). It was dredged from a depth of about $550 \mathrm{~m}$ off the Lofoten Islands and belongs to the bourgueticrinids, a type known at the time only from fossils. The species, now named Conocrinus lofotensis (Sars, 1868), was described in detail by M. Sars in 1868 , who contended that the deep-sea floor was a refuge for living fossils. The find caused extreme interest in the scientific world that such a living fossil, a sort of degraded Apiocrinite (Carpenter, 1884 , p. 246), was still to be found in Recent seas. This first living example of a stalked crinoid recovered from a known depth was one of the reasons that Thomson and Carpenter, both interested in these animals, persuaded the British Admiralty to use the navy paddle-steamers HMS Lightning and HMS Porcupine for deep-sea dredging operations (Thomson, 1873).

It should be noted that a few years earlier, in 1853, a strange asteroid was dredged off Norway and described as Brisingia endecacnemos (Asbjörnsen, 1856). Its morphology appeared intermediate between asteroids and ophiuroids, and it was therefore also considered to be an archaic species, much like the stalked crinoids (Asbjörnsen, 1856). Yet brisingids are specialized modern asteroids that use their long, flexible arms for suspension feeding (Lawrence, 1987).

\section{Why the early records vanished from the textbooks}

The John Ross expedition with its ground-breaking soundings to an alleged depth of more than $1950 \mathrm{~m}$ and the recovery of a basket star from such a depth was initially neglected and not cited in the pertinent literature of the early 19th century (Rice, 1975). It was only "rediscovered" after opponents of the azoic theory of Forbes were assembling the facts that would prove that animal life existed on deep-sea floors. Afterwards however and well into the 21 st century, the John Ross episode became uncritically cemented in the deep-sea literature.

When in 1761/1762 the first modern stalked crinoids were reported from the Caribbean, they came from an unknown depth and the scientific interest centered more on their Mesozoic appearance and their role as "living fossils" (e.g. Walch, 1769). The deep-sea fishes that were described between 1770 and 1810 likewise came from unknown depths or even surface waters. Only later did we learn that these were bathyal species. Risso (1810) was the first to develop a bathymetric distribution scheme for fishes but this was not tied to actual

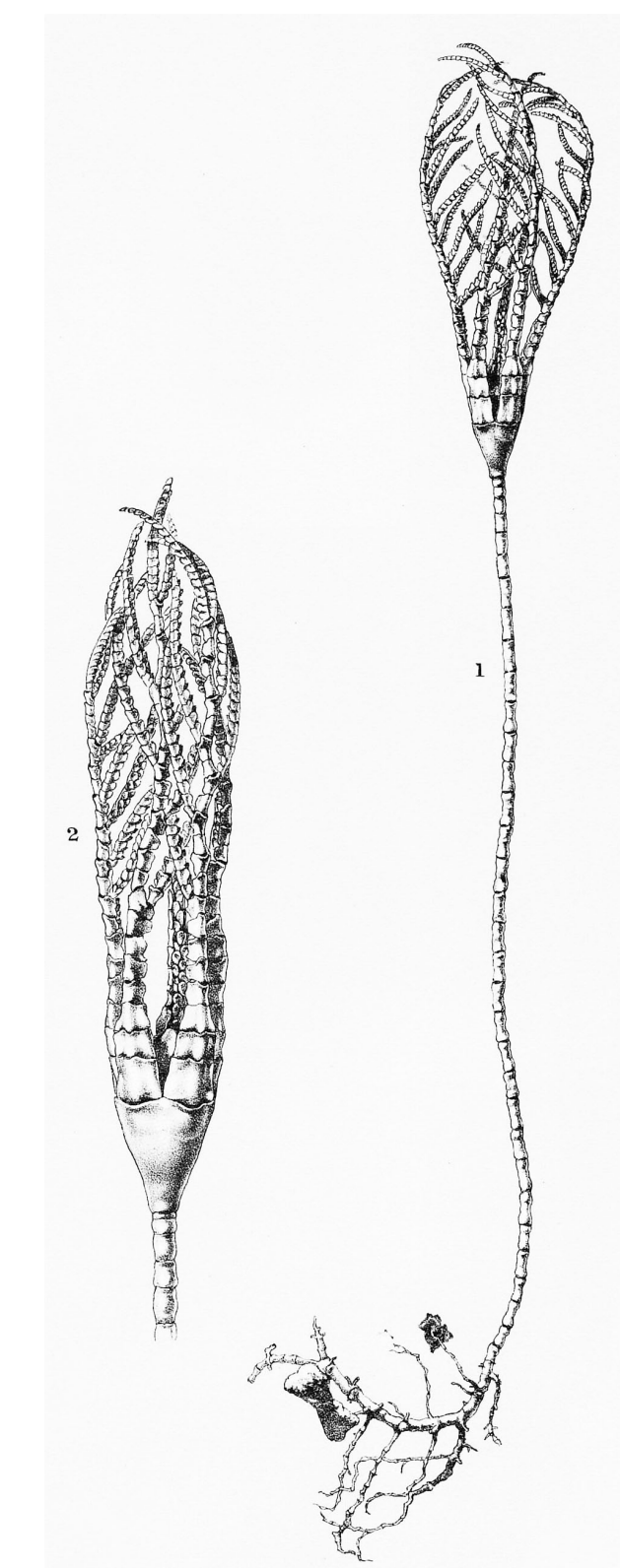

Figure 4. Conocrinus lofotensis (Sars, 1868) (Carpenter, 1884, pl. 9, pars; as Rhizocrinus lofotensis Sars) from the northern Atlantic.

soundings and open to criticism. The reasons why deep-sea organisms were not recognized as such in the 19th century were thus manyfold.

Deep-sea organisms brought up by fishing or sounding lines were considered for a long time less reliable than dredgings. It was suspected that organisms might have become entangled higher up in the water column. This also applied to organisms like stalked crinoids, brittlestars or basket stars that are now known to be strictly benthic (Rice, 1975).

For demersal deep-sea fishes, a bathymetric zonation was developed only after the Challenger expedition (Günther, 1887). This took even considerably longer for bathypelagic 
fishes. Some researchers maintained that there was in the open ocean a zone devoid of life between the surface waters and the deep-sea bottom (Agassiz, 1888), while others believed in the existence of an intermediate fauna. This was only settled in favor of the second opinion after the German Valdivia expedition (Chun, 1900).

In his masterly treatment of the history of deep-sea research, Murray (1895) gathered all the results of deep-sea explorations that pointed to rich life on deep-sea floors, as had Thomson (1873) done before with lesser depth. It was these texts that hailed John Ross' expedition as an early record-breaking cruise and took the published results at face value. At the same time Murray omitted (in contrast to Thomson, 1873) the occurrences of the deep-water stalked crinoids from the Caribbean, although they were of course treated in the Challenger report on the stalked crinoids (Carpenter, 1884). Murray's chapter was highly influential and inspired many subsequent historical summaries either directly or indirectly. It should therefore come as no surprise that the early finds of Caribbean crinoids were omitted in most historical introductions (e.g. Murray and Hjort, 1912; Menzies et al., 1973; Gage and Tyler, 1991; Ramirez-Llodra et al., 2010), a rare exception being Mills (1983). Murray also confounded Gorgonocephalus arcticus with G. caputmedusae (=G. linckii), and the latter name persisted in many of the above-mentioned texts.

While in the times of Forbes the deep sea started at around the shelf break, during the 20th century the deep sea was equated by many with deeper bathyal depths or the abyss, i.e., water-depths of more than 500 or $1000 \mathrm{~m}$ (e.g. Canganella and Kato, 2007). This was perhaps an additional reason that the historical finds of bathyal animals were neglected.

\section{Conclusions}

The published record of deep-sea organisms goes back to the middle of the 18th century. Stalked crinoids from the Caribbean were the first among these early records. Originally they were not perceived as deep-sea animals yet were instrumental in developing the concept of "living fossils". Consequently, these finds were discussed in the paleontologic literature but largely omitted in the field of marine biology.

When the systematic exploration of the deep sea commenced during the early 19th century, only dredgings from a "known" depth (even if that depth-sounding was grossly in error) were accepted by the scientific community as reliable indicators of deep-sea life. Apart from 1860, epizoans on telegraph cables that were brought up for repair also became accepted as proof of life in the deep sea. The catch of a basket star at great depths during the John Ross expedition only became scientific commonplace when Thomson,
Carpenter and others started to assemble the facts that would disprove Forbes' theory of the azoic deep sea.

Accidental catches that would emerge as important evidence of deep-sea life such as those of stalked crinoids from the Caribbean persistently remained neglected through much of the 20th century. This has much to do with the lasting influence of Murray's remarkable chapter on the history of oceanography and deep-sea research in the Challenger report summary (Murray, 1895), from which some errors and omissions were perpetuated in the newer literature. It is therefore important that the historical literature is carefully read, evaluated and compared with the original sources, and summary treatments from the 20th and 21 st century should not be uncritically followed.

Acknowledgements. We wish to thank Michael J. Simms for information on crinoids figured by Ellis, and Sabine Stöhr for her help with species determinations and literature on basket stars. Sabine Stöhr also critically read and commented on the manuscript. M. Reilly provided information about the Ellis specimen of Cenocrinus asterius. We would like to thank C. Messing and an anonymous referee for the constructive comments on an earlier draft of the manuscript.

Edited by: H. Kitazato

\section{References}

Agassiz, A.: Three Cruises of the United States Coast and Geodetic Survey Steamer "Blake" in the Gulf of Mexico, in the Caribbean Sea, and along the Atlantic Coast of the United States, from 1877 to 1880,2 Vol., Houghton, Mifflin and Company, Cambridge Massachusetts, $314+220$ pp., 1888 .

Aldrovandi, U.: De animalibus insectis libri septem, cum singulorum iconibus ad vivum expressis, Bellagamba, Bologna, $10+$ 810 pp., 1602.

Améziane, N. and Baumiller, T. K.: In situ stalk growth rates in tropical western Atlantic sea lilies (Echinodermata: Crinoidea), J. Exp. Mar. Biol. Ecol., 353, 211-220, 2007.

Améziane, N., Bourseau, J. P., Heinzeller, T., and Roux, M.: Les genres Cyathidium et Holopus au sein des Cyrtocrinida (Crinoidea: Echinodermata), J. Nat. Hist., 33, 439-470, 1999.

Anderson, T. R. and Rice, T.: Deserts on the sea floor: Edward Forbes and his azoic hypothesis for a lifeless deep ocean, Endeavour, 30, 131-137, 2006.

Asbjörnsen, P. C.: Description d'un nouveau genre des Astéries, Fauna litoralis Norvegiae, 2, 95-101, 1856.

Ascanius, P.: Icones rerum naturalium, ou figures enluminées d'histoire naturelle du nord, second cahier, Möller imprimérie, Copenhague, DK, 8 pp., 10 Tab., 1772.

Baumiller, T. K. and Messing, C. G.: Stalked crinoid locomotion, and its ecological and evolutionary implications, Palaeontol. Electron., 10, 1-10, 2007.

Baumiller, T. K., LaBarbera, M., and Woodley, J. D.: Ecology and functional morphology of the isocrinid Cenocrinus asterius (LIN- 
NAEUS) (Echinodermata: Crinoidea): in situ and laboratory experiments and observations, B. Mar. Sci., 48, 731-748, 1991.

Blake, J. F.: Echinoderms, edited by: Tate, R. and Blake, J. F.: in: The Yorkshire Lias, Van Voorst, London, 475 pp., 439-446, 1876.

Bloch, M. E. and Schneider, J. G.: Systema Ichthyologiae iconibus cx illustratum, Sander, Berlin, $60+584$ pp., 110 Tab., 1801.

Bruun, A. F.: Animal life of the deep sea bottom, in: The Galathea Deep Sea Expedition 1950-1952, edited by: Bruun, A. F., Greve, S., Mielche, H., and Spärck, R., George Allen and Unwin Ltd, London, 149-195, 1956.

Canganella, F. and Kato, C.: Deep Ocean Ecosystems, in: Encyclopedia of Life Sciences, edited by: Battista, J., Bynum, W. F., Cooper, D., Cox, M., Delves, P., Harper, D., Levitan, I., Melino, G., Phillips, G., Roberts, K., Tickle, C., and Wood, B., Vol. 22, Wiley, Chichester, 646 pp., 229-238, 2007.

Carpenter, P. H.: Report on the Scientific Results of the Voyage of H. M. S. Challenger during the years 1873-1876, Zoology, vol. 11, part XXXII, Report upon the Crinoidea, First Part, General morphology, with descriptions of the stalked crinoids, Her Majesty's Stationery Office, London, 1-442, pls. 1-72, 1884.

Chun, C.: Aus den Tiefen des Weltmeeres, Schilderungen von der Deutschen Tiefsee-Expedition, Gustav Fischer, Jena, 549 pp., 1900.

Clark, H. L.: Catalogue of recent ophiurans: Based on the collection of the Museum of Comparative Zoölogy, Memoirs of the Museum of Comparative Zoölogy at Harvard College 25, 165-376, 20 pls., 1915.

Darwin, C.: On the Origin of Species by Means of Natural Selection, or the Preservation of Favoured Races in the Struggle for Life, John Murray, London, 502 pp., 1859.

David, J., Roux, M., Messing, C. G., and Ameziane, N.: Revision of the pentacrinid stalked crinoids of the genus Endoxocrinus (Echinodermata, Crinoidea), with a study of environmental control of characters and its consequences for taxonomy, Zootaxa, 1156, 1-50, 2006.

Donovan, S. K. and Pawson, D. L.: A new species of the sessile crinoid Holopus d'Orbigny from the tropical western Atlantic, with comments on holopodid ecology (Echinodermata: Crinoidea: Holopodidae), Zootaxa, 1717, 31-38, 2008.

d'Orbigny, A.: Mémoire sur une seconde espèce vivante de la famille des Crinoïdes ou Encrines, servant de type au nouveau genre Holope (Holopus), Magasin de Zoologie, 7, 1-8, pl. 3, 1837.

Ellis, J.: An Essay towards a Natural History of the Corallines and other Marine Productions of the like Kind Commonly found on the Coasts of Great Britain and Ireland, to which is added the Description of a large Marine Polype taken near the North Pole, by the Whale-fishers, in the Summer 1753, printed for the Author, London, 103 pp., 1755.

Ellis, J.: An Account of an Encrinus, or Starfish, with a Jointed Stem, Taken on the Coast of Barbadoes, Which Explains to What Kind of Animal Those Fossils Belong, Called Starstones, Asteriae, and Astropodia, Which Have been Found in Many Parts of This Kingdom: in a Letter to Mr. Emanuel Mendes da Costa, F. R. S., Philos. T. R. Soc., 52, 357-365, 1762.

Emson, R. H., Mladenov, P. V., and Barrow, K.: The feeding mechanism of the basket star Gorgonocephalus arcticus, Can. J. Zoolog., 69, 449-455, 1991.
Fedotov, D. M.: Die Morphologie der Euryalae, Z. Wiss. Zool. Abt. A, 127, 403-528, 1926.

Forbes, E.: Report on the Mollusca and Radiata of the Aegean Sea, and on their distribution, considered as bearing on geology, Report of the British Association for the Advancement of Science for 1843, 130-193, 1844.

Gage, J. D. and Tyler, P. A.: Deep-Sea Biology: a Natural History of Organisms at the Deep-Sea Floor, Cambridge University Press, Cambridge, UK, 504 pp., 1991.

Gervais, F. L. P.: Encrine, in: Dictionnaire Pittoresque d'Histoire Naturelle et des Phénomènes de la Nature, tome troisième, edited by: Guérin, F.-E., Lenormand, Paris, 49-50, pl. 147, 1835.

Gessner, C.: Conradi Gesneri medici Tigurini Historiae animalium liber IIII, qui est de piscium \& aquatilium animantium natura, Froschauer, Zürich, $20+1297$ pp., 1558.

Gmelin, J. F.: Caroli a Linné, systema naturae, Tom. I, Pars III, Beer, Leipzig, 1033-1516, 1789.

Grieg, J. A.: Die Ophiuriden der Arktis, Fauna Arctica Bd. I, 259286, 1990.

Grimmer, J. C. and Holland, N. D.: The structure of a sessile, stalkless crinoid (Holopus rangii), Acta Zool., 71, 61-67, 1990.

Guettard, J. E.: Mémoire sur les encrinites et les pierres étoilées, dans lequel on traitera aussi des entroques, etc., Académie des Sciences Paris, Mém. pour 1755, 224-263, 318-354, pl. 8, 9, 14-16, 1761.

Günther, A.: Report on the Scientific Results of the Voyage of H. M. S. Challenger during the years 1873-1876, Zoology, vol. 22, part LVII, Report on the Deep-Sea Fishes, Her Majesty's Stationery Office, London, $43+335$ pp., 73 pls., 1887.

Hendler, G.: Class Ophiuroidea, in: Taxonomic Atlas of the Benthic Fauna of the Santa Maria Basin and the Western Santa Barbara Channel, edited by: Blake, J. A., Scott, P. H., and Lissner, A., Vol. 14, Miscellaneous Taxa, 113-179, Santa Barbara Museum of Natural History, Santa Barbara, 1996.

Hendler, G., Miller, J. E., Pawson, D. L., and Kier, P. M.: Sea Stars, Sea Urchins, and Allies: Echinoderms of Florida and the Caribbean, 392 pp., Smithsonian Institution Press, Washington D.C., 1986.

Hermann, J.: Schreiben über ein neues amerikanisches Fischgeschlecht Sternoptyx diaphana, Der Naturforscher, 16, 8-36, 1781 .

Herring, P.: The Biology of the Deep Ocean, Oxford University Press, Oxford, 314 pp., 2002.

Koehler, R.: Résultats des campagnes scientifiques accomplies sur soon yacht par Albert I Prince Souverain de Monaco, Fascicule 34, Echinodermes provenant des campagnes du yacht PrincesseAlice (Astéries, Ophiures, Echinides et Crinoïdes), Imprimérie de Monaco, Monaco, 317 pp., 32 pl., 1909.

Lamarck, J.-B. P. A. de: Histoire naturelle des animaux sans vertèbres, v. 2, 1-568, Verdière, Paris, 1816.

Lawrence, J.: A Functional Biology of Echinoderms, Croom Helm, London, 340 pp., 1987.

Leach, W. E.: Descriptions des nouvelles espèces d'Animaux découvertes par le vaisseau Isabelle dans un voyage au pôle boréal, Journal de Physique, de Chimie, d'Histoire Naturelle et des Arts 88, 462-467, 1819.

Linck, J. H.: De Stellis Marinis Liber Singularis, Schuster, Leipzig, $23+108$ pp., 42 pl., 1733. 
Linné, C.: [Linnaeus, Carolus], Museum Adolphi Friderici Regis, Typographia Regia, Holmiae (Stockholm), $30+103$ pp., 33 pl., 1754.

Linné, C.: [Linnaeus, Carolus], Systema naturae: 10th edition Tomus 1, Laurentius Salvius, Holmiae (Stockholm), 1-824, 1758.

Linné, C.: [Linnaeus, Carolus], Systema naturae: 12th edition Tomus 1 part 2, Laurentius Salvius, Holmiae (Stockholm), 5331327, 1767.

Lütken, C.: Om Vestindiens Pentacriner med nogle Bemaerkinger om Pentacriner og Sölilier i Almindelighed, Videnskabelige Meddellser fra den naturhistoriske Forening i Kjöbenhavn 1316, 195-245, 1864.

Lyman, T.: Report on the Scientific Results of the Voyage of $\mathrm{H}$. M. S. Challenger during the years 1873-1876, Zoology, vol. 5, part XIV, Report on the Ophiuroidea, Her Majesty's Stationery Office, London, 1-386, 48 pls., 1882.

Macurda Jr., D. B. and Meyer, D. L.: Feeding posture of modern stalked crinoids, Nature, 247, 394-396, 1974.

Martens, F.: Spitzbergische oder Groenlandische ReiseBeschreibung gethan im Jahr 1671, Gottfried Schultzen, Hamburg, $8+135$ pp., 16 Taf., 1675.

Menzies, R. J., George, R. Y., and Rowe, G. T.: Abyssal Environment and Ecology of the World Oceans, John Wiley and Sons, New York, 488 pp., 1973.

Meyer, D. L., Messing, C. G., and Macurda Jr., D. B.: Zoogeography of tropical western Atlantic Crinoidea, B. Mar. Sci., 28, 412-441, 1978.

Miller, J. S.: A Natural History of the Crinoidea, or Lily-shaped, C. Frost, Bristol, 150 pp., 1821.

Mills, E. L.: Problems of deep-sea biology: an historical perspective, in: Deep-sea Biology, edited by: Rowe, G. T., Wiley, New York, $9+560$ pp., 1-79, 1983.

Murray, J. and Hjort, J.: The Depths of the Ocean, Macmillan and Co., London, $20+821$ pp., 1912.

Murray, L.: Report on the Scientific Results of the Voyage of H. M. S. Challenger during the years 1873-1876. A Summary of the Scientific Results, vol. 1, Her Majesty's Stationery Office, London, $54+796$ pp., 1895 .

Mylius, C.: Beschreibung einer neuen Grönländischen Thierpflanze, in einem Sendschreiben an Se. Hochwohlgebohrnen, Hrn. Albrecht von Haller, Ammann der Stadt Bern, Präsidenten der Königlichen Gesellschaft der Wissenschaften zu Göttingen ec, Linde, London, 19 pp., 1753.

Parra, A.: Descripcion de diferentes piezas de historia natural las mas del ramo maritime, representadas en setenta y cinco laminas, Imprenta de la Capitanía General, La Havana, 200 pp., 1787.

Pawson, D. L., Vance, D. J., Messing, C. G., Solis-Marin, F. A., and Mah, C. L.: Echinodermata of the Gulf of Mexico, in: Gulf of Mexico - Origins, Waters, and Biota, edited by: Felder, D. L. and Camp, D. K., Vol. 1 Biodiversity, Texas A\&M Press, College Station, Texas, 1177-1204, 2009.

Ramirez-Llodra, E., Brandt, A., Danovaro, R., De Mol, B., Escobar, E., German, C. R., Levin, L. A., Martinez Arbizu, P., Menot, L., Buhl-Mortensen, P., Narayanaswamy, B. E., Smith, C. R., Tittensor, D. P., Tyler, P. A., Vanreusel, A., and Vecchione, M.: Deep, diverse and definitely different: unique attributes of the world's largest ecosystem, Biogeosciences, 7, 2851-2899, doi:10.5194/bg-7-2851-2010, 2010.
Reich, M.: The "Swabian Caput Medusae" (Jurassic Crinoidea, Germany), in: Echinoderms, edited by: Harris, L. G., Böttger, S. A., Walker, C. W., and Lesser, M. P., Durham - Proceedings of the 12th International Echinoderm Conference, Taylor \& Francis, London, 61-65, 2010.

Rice, A. L.: The oceanography of John Ross's Arctic Expedition of 1818; a re-appraisal, Journal of the Society for the Bibliography of Natural History, 7, 291-319, 1975.

Rice, A. L., Burstyn, H. L., and Jones, A. G. E.: G.C. Wallich M.D.-Meglomaniac or mis-used oceanographic genius?, Journal of the Society for the Bibliography of Natural History, 7, 423450, 1976.

Risso, A.: Ichthyologie de Nice, ou Histoire Naturelle des Poissons du Departement des Alpes Maritimes, F. Schoell, Paris, $36+388$ pp., 11 pls., 1810.

Risso, A.: Histoire Naturelle des Principales Productions de l'Europe Méridionale et Principalement de celles des Environs de Nice et des Alpes Maritimes, Tome cinquième, F.-G. Levrault, Paris, 402 pp., 1826.

Rondelet, G.: Universae aquatilium Historiae pars altera, cum veris ipsorum Imaginibus, Bonhomme, Lyon, $12+252$ pp., 1555.

Rosenberg, R., Dupont, S., Lundälv, T., Nilsson Sköld, H., Norkko, A., Roth, J., Stach, T., and Thorndyke, M.: Biology of the baskel star Gorgonocephalus caputmedusae (L.), Mar. Biol., 148, 4350, 2005.

Rosinus, M. R.: Tentaminis de Lithozois ac Lithophytis etc., Sauer, Hamburg, $10+92$ pp., 10 pls., 1719.

Ross, J.: A voyage of discovery, made under the orders of the Admiralty, in His Majesty's Ships Isabella and Alexander, for the purpose of exploring Baffin's Bay, and inquiring into the probability of a North West Passage, Murray, London, $39+252$ pp. 1819.

Ross, J. C.: A voyage of discovery and research in the southern and antarctic regions during the years 1839-43, Volume 2, Murray, London, $10+447$ pp., 1847 .

Rozwadowski, H. M.: Fathoming the Ocean: The Discovery and Exploration of the Deep sea, The Belknap Press of Harvard University Press, Cambridge Massachusetts, 276 pp., 2005.

Rudwick, M. J. S.: Bursting the Limits of Time. The Reconstruction of Geohistory in the Age of Revolution, The University of Chicago Press, Chicago, 708 pp., 2005.

Rumph, G. E.: D’Amboinsche Rariteitkamer, François Halma, Amsterdam, 340 pp., 60 pls., 1705.

Sars, M.: [Report on Rhizocrinus lofotensis], Videnskabelige Selskabs Forhandlinger 1864, p. 127., 1864.

Sars, M.: Mémoires pour servir à la connaissance des crinoïdes; I: Du Rhizocrinus lofotensis M. Sars, nouveau genre vivant des crinoïdes pédicellés, dits lis de mer, II: Du pentacrinoïde de l'Antedon Sarsii (Alecto) Duben et Koren, Brøgger \& Christie, Christiania, 65 p., 6 pl., 1868.

Shaw, G.: Description of the Stylephorus chordates, a new fish, Transactions of the Linnean Society, vol. 1, 90-92, Pl. 6, 1791.

Snelgrove, P. V. R. and Grassle, J. F.: Deep-sea fauna, in: Encyclopedia of Ocean Sciences, edited by: Steele J. H., 2nd Edn., vol. 2, Elsevier, Amsterdam, 55-66, 2008.

Stimpson, W.: Synopsis of the marine Invertebrata of Grand Manan, Smithsonian Contributions to Knowledge 6, article 5, 1-67, 1854. 
Stöhr, S.: Gorgonocephalus arcticus Leach, 1819, in: World Ophiuroidea database, edited by: Stöhr, S., O'Hara, T., and Thuy, B., available at: http://www.marinespecies.org/ophiuroidea/aphia. php?p=taxdetails\&id=124966 (last access: 8 July 2014), 2014.

Thistle, D.: The deep-sea floor: an overview, in: Ecosystems of the World 28: Ecosystems of the Deep Oceans, Chapter 2, edited by: Tyler, P. A., 5-37, Elsevier, Amsterdam, 569 pp., 2003.

Thomson, C. W.: Sea Lilies, The Intellectual Observer, August 1864, 1-11, 1864.

Thomson, C. W.: The depths of the sea, Macmillan and Co., London, 527 pp., 1873.

Tyler, P. A.: Deep-sea ophiuroids, Oceanography and Marine Biology, Annual Reviews, 18, 125-153, 1980.
Tyler, P. A.: Introduction, in: Ecosystems of the World 28: Ecosystems of the Deep Oceans, Chapter 1, edited by: Tyler, P. A., Elsevier, Amsterdam, 569 pp., 1-3, 2003.

Walch, J. E. I.: Die Naturgeschichte der Versteinerungen zur Erläuterungen der Knorrischen Sammlung von Merkwürdigkeiten der Natur, Des zweyten theils zweyter Abschnitt, Felsecker, Nürnberg, 303 pp., 50 pl., 1769.

Wallich, G. C.: The North Atlantic Sea Bed: comprising a diary of the voyage on board H. M. S. Bulldog, in 1860; and observations on the presence of animal life, and the formation \& nature of organic deposits at great depths in the ocean, Van Voorst, London, 160 pp., 1862. 